\title{
ВПЛИВ ІДЕЙ РЕФОРМАТОРСЬКОЇ ПЕДАГОГІКИ НА РОЗВИТОК ВІТЧИЗНЯНОЇ ПЕДАГОГІЧНОЇ ДУМКИ
}

\author{
Тєсцова О. О., Пишногуб М. В.
}

\section{ВСТУП}

Сучасній людині на тлі стрімко змінюваного світу необхідно відходити від практики пізнання й відтворення вже накопичених знань, розумових стереотипів, досвіду поведінки, накопиченого людством. У середовищі, що інтенсивно змінюється, комфортно може існувати людина, здатна активно брати участь у різних суспільних сферах життя, при цьому проявляючи ініціативність, пізнавальну активність, прагнення до відкриття нового. Вітчизняна система освіти неповною мірою сприяє розвитку та формуванню людської індивідуальності, становленню творчої особистості, здатної до соціалізації та комунікації. Саме тому актуальною нині $\epsilon$ проблема заміни системи освіти й навчання, орієнтована в основному на репродуктивну передачу знань, на систему, що орієнтується на навчання та виховання активної творчої особистості, яка б володіла здібностями до самостійного пізнання нового, була б підготовлена до свідомого й грунтовного вибору свого подальшого життєвого шляху, могла б вільно та легко самореалізуватися в різних видах особистісної й суспільно значущої діяльності.

Зазначені вимоги до сучасної успішної особистості якнайбільше та якнайповніше стосуються «реформаторської педагогіки». Ї̈̈ значимість необхідно розглядати як педагогічну теорію і практику, що виходить від природи дитини, іiі природних інтересів, нахилів і потреб, спрямовану на розвиток iii творчих сил і потенційних можливостей в умовах свободи від державно-бюрократичної регламентації з метою суспільного оновлення та прогресу. Інтеграція численних ідей реформаторської педагогіки чинить величезний вплив на сучасну українську педагогічну науку й відображається в ній, що, у свою чергу, вимагає нових вимог до системи освіти, учасників освітнього процесу, становлення й розвитку «нової української школи».

\section{1. Історіографічний аналіз впливу вітчизняної реформаторської педагогіки на розвиток сучасної української школи}

Дослідження проблеми розвитку реформаторської педагогіки неможливе без аналізу впливу ії ідей на подальший розвиток вітчизняної педагогічної науки. Цьому питанню присвятили праці такі науковці, 
як О. Барило, Н. Гупан, І. Зайченко, О. Караманов, В. Кемінь, О. Квас, Т. Кравцова， Ю. Литвина, Н. Осьмук, О. Перетятько, С. Поліщук, А. Растригіна, А. Сбруєва, О. Сухомлинська, Ю. Чопик та інші.

Аналіз наукових джерел свідчить про різні періоди активізації інтересу до ідей зарубіжної реформаторської педагогіки кінця XIX початку XX століття, зокрема, Англії, у вітчизняній педагогіці. Перший період визначається багатьма науковцями 3 кінця XIX (70-ті роки) до 30-х років XX століття, причому в ньому можна виокремити два етапи: 70-ті роки XIX століття - 1919 рік, і 20-ті - 30-ті роки XX ст. Перший етап характеризується становленням теоретичних основ реформаторського руху, вивченням основних методичних, змістових та організаційних принципів діяльності західних експериментальних навчально-виховних закладів, виникненням реформаторських течій у вітчизняній педагогіці.

Зазначимо, що зміни в суспільно-політичному житті України досліджуваного періоду - скасування кріпосного права, зростання селянських зворушень, розвиток революційно-демократичного руху, повалення самодержавства - актуалізували питання про необхідність реформування освіти в сенсі доступу до навчання дітей із нижчих верств суспільства, що вимагало реформування насамперед початкової та середньої школи, розвитку освіти для жінок, створення багатопрофільної шкільної системи тощо.

Такі відомі педагоги того часу, як К. Ушинський, М. Демков, Я. Мамонтов, В. Дурдуківський, Я. Чепіга, С. Русова та інші, виступили за реформування старої школи, яка трималася на муштрі, тілесних покараннях, неповазі до учнів і характеризувалася низьким рівнем знань, що відірвані від життя й не відповідали потребам суспільства. Усвідомлюючи та приймаючи принципи реформаторської педагогіки Німеччини, Англії, США, вони основними завданнями навчання й виховання учнів уважали «формування всебічно та гармонійно розвиненої особистості, розвиток природних здібностей дитини, іiі можливостей i талантів; формування людини соціально зрілої, високоморальної, розумово розвиненої й працелюбної за умов усунення зі школи будь-яких факторів, які гальмують вільний природний саморозвиток дитини» ${ }^{1}$. С. Русова зазначала: «Бажано було б дуже зробити хоч десь на Вкраїні спробу в родинному житті українськими засобами провести найкращі сучасні педагогічні ідеали, виховати розумну працьовиту дитину, не одірвану від свого народу,

\footnotetext{
${ }^{1}$ Бауманн Ю. Введение в педагогику. История педагогических теорий: Общая педагогика. Санкт-Петербург : Тип. М.О. Вольфа, 1905. С. 12. 
a, навпаки, пов'язану 3 ним пошаною до всього свого» ${ }^{2}$. Педагоги застерігали проти традиційного догматичного навчання й закликали до того, щоб українські вчителі орієнтувалися на здобутки західноєвропейської школи, насамперед німецької та англійської.

У цей період під впливом поглядів західноєвропейських педагогівреформаторів набувають розвитку ідеї природовідповідності навчально-виховного процесу, гуманного ставлення до учнів, активізації їхньої самодіяльності, вільної фізичної активності дитини, упровадження шкільного самоврядування, трудового характеру навчання й виховання.

Основним підходом до організації навчально-виховної діяльності у вітчизняній педагогіці, що сформувався під впливом західноєвропейського реформаторського руху, став педоцентричний, за якого дитина була центром навчального та виховного процесу, спрямованого на забезпечення іiі інтересів i прагнень, розвиток трудових і пізнавальних здібностей, формування умов для саморозвитку й самовиховання.

У 1919 році Наркомос республіки ухвалив Положення про єдину трудову школу УСРР, відповідно до якого передбачалося запровадження безплатного навчання дітей обох статей 38 років, а також їх спільне навчання, скасування старих типів шкіл, створення єдиної трудової школи-комуни, заборона релігійного виховання. У Положенні трудовий метод визнано як основу організації навчальновиховного процесу у вітчизняній освіті. Як зауважувала С. Русова, «праця в сучасному вихованні - це метод, яким кожне знання фіксується в дитячій свідомості тим, що воно здобувається дитячою рукою: через руку в розум» ${ }^{3}$. Педагог, визначаючи роль трудового навчання у вихованні дітей, наголошувала на тому, що саме праця сприяє найбільшому розвиткові самостійної творчості й індивідуальності учнів. Окрім того, виховний характер праці С. Русова вбачала у формуванні охайності, працелюбності, ініціативності. У цьому сенсі вона була прихильницею поглядів провідних педагогівреформаторів Англії, у школах якої виховувалася така ж повага до фізичної праці, як і до розумової.

На поширення практико-орієнтованого підходу в навчанні в 20-ті 30-ті роки ХХ століття суттєво вплинуло видання Наркомосом УРСР у 1920 році Декларації про соціальне виховання дітей, яка визначала основні принципи політики Радянської України в галузі освіти й

\footnotetext{
${ }^{2}$ Русова С.Ф. Дидактика. Вибрані пед. твори : у 2 кн. Київ : Либідь, 1997. Кн. 2. C. 134-300.

${ }^{3}$ Русова С. Дошкільне виховання. Катеринослав, 1918. С. 53.
} 
виховання підростаючого покоління. При цьому робота всіх освітніх $\mathrm{i}$ виховних закладів будувалася за трудовим принципом і за своїми завданнями та змістом утворювала єдину систему професійної освіти. На думку тодішнього Наркому освіти Г. Гринька, таке рішення виходило 3 важливих потреб українського народу: по-перше, 3 необхідності підготовки кваліфікованих робітників для потреб відбудови господарства; по-друге, з необхідності організації захисту дітей і турботи про них через велику кількість сиріт і напівсиріт, які 3'явилися в результаті революції та війни.

Відповідно до Декларації, замість шкіл, рекомендувалося створювати дитячі будинки та дитячі комуни, що свідчило про початок створення закладів соціального виховання в Україні. Метою створення нових навчально-виховних закладів була охорона дитинства, яка розумілася в контексті боротьби з безпритульністю й сирітством, а отже, передбачала насамперед поліпшення умов життя дітей. Тобто держава намагалася створити елементарні умови для виживання дітей у тяжких умовах, що склалися після революції та громадянської війни. «Декларація висунула ідею так званого «захисту дитинства», завданням якого було взяти на облік усіх дітей віком від 7 до 15 років, як тих, які вже ввійшли в систему соціального виховання, так i тих, що не відвідують жодної освітньо-виховної установи; використати всі засоби для забезпечення прав кожної дитини на освіту, матеріальне забезпечення, виховання, охорону здоров'я; вилучити дитину «з вулиці», передати через колектор або розподільник до виховного закладу (боротьба з безпритульністю); захистити права і тієї дитини, яка живе в сім'ї, але потребує допомоги» ${ }^{4}$. При цьому визначалося, що основою перевиховання дітей у нових закладах має стати трудове виховання.

Саме в цей період розкривається педагогічний талант ще одного вітчизняного педагога-гуманіста - А. Макаренка, який створив власну концепцію виховання, засновану на поверненні до його національних витоків - християнських моральних цінностей, фізичної праці, співробітництва учнів і вчителя. Як зауважував сам педагог, він намагався йти «за якостями особи, іiі нахилами та здібностями, спрямовувати цю особу в найпотрібніший для неї бік» 5 .

4 Харук Т.Я. Становлення закладів для дітей-сиріт та дітей, позбавлених батьківського піклування, на різних етапах розвитку суспільства в Україні. Збірник наукових пращь Хмельницького інституту соціальних технологій Університету «Украӥна». 2011. № 3. С. 190. URL: http://nbuv.gov.ua/UJRN/Znpkhist_2011_3_41 (дата звернення: 18.04.2020).

5 Макаренко А.С. Методика виховної роботи. Київ : Радянська школа, 1990. C. 151 . 
Варто зауважити, що вітчизняні педагоги-новатори, наслідуючи ідеї реформаторської педагогіки Західної Свропи, зокрема й англійської, підходили до їх реалізації творчо й прагнули зберегти та розвинути національні особливості вітчизняної школи. Однією 3 основних цілей виховання й навчання вони, як і педагоги-реформатори Дж.С. Мілль, Г. Спенсер, С. Редді, Дж.Г. Бедлі, О. Нейлл, уважали формування людинигромадянина, патріота, носія найкращих наукових і культурних традицій свого народу. У статті «Національність і національна школа» Я. Чепіга тлумачить поняття «національне виховання» як «не шовіністичне, не приправлене «дутим» патріотизмом, а виховане в дусі нації, в дусі мови, в iii переказах, віруваннях, іiі звичаях, іiі історії, іï культури, національної творчості, того, про що писали й казали найліпші представники нації, всього що народ або нація пережили, бачили, чули, виробили, що придбали найцікавішого, найкорисливішого в своїм розвитку».

В Україні національне виховання було пов'язане 3 відстоюванням права викладати й учитися рідною мовою, яке зумовлене боротьбою українського народу в цей період за незалежність держави. Про необхідність навчати дітей українською мовою говорив М. Грушевський: «Вчити добре можна тільки такою мовою, котру ученики добре знають і розуміють. ... і таке правило в шкільній науці, що вчити треба ученика мовою для нього зрозумілою» ${ }^{7}$. У законопроекті «Про ученнє українською мовою» (1908р.) він визначив основні принципи мовної політики в освіті: «1) щоб по тих сторонах, де живе український народ, у народнїх школах учено українською мовою; 2) руської мови щоб учили обов'язково; 3) книжки до учення щоб були приладжені до розуміння дітей українських до потреб тамошнього життя» ${ }^{8}$.

Я. Чепіга, наслідуючи погляди М. Грушевського, зауважував: «Мова народів як психофізичний акт має всі ознаки національності. Кожному слову і навіть деяким окремим звукам надано конкретного змісту, поєднаного певними уявленнями. I такі розуміння, як любов, добро, правда тощо, набувають у кожного народу особливих національних рис»; а висуваючи вимоги до вчителя, акцентував, що шкала повинна мати «за вчителя особу однієї національності 3 дитиною, виховану на ріднім грунті з нею. А ті, хто не своєю волею мусить вчити в чужій школі, повинні прийняти культуру, мову, національні ідеали того народу, дітей якого вони мають учити» .

${ }^{6}$ Чепіга Я. Національність і національна школа. Світло. 1910. № 1. С. 27.

${ }^{7}$ Грушевський М. Про українську мову і українську школу / передм. Я. Гояна. 2-е вид. Київ : Веселка, 1991. С. 15.

${ }^{8}$ Там само. С. 16.

9 Чепіга Я.Ф. Самовиховання вчителя. Київ : Українська педагогічна бібліотека, 1914. C. $30,33$. 
Національне виховання також є провідним принципом педагогічної діяльності С. Русової: «Першим кроком демократизації народної освіти повинна бути іiі націоналізація, оскільки, лише націоналізуючи народну освіту, можна ввести іï в свідомість народів, бо тільки рідна мова $\epsilon$ найплодотворнішим, найприроднішим органом думки для мільйонів людей». Педагог виділяє найкращі методики вивчення рідної мови, до яких зараховує вільні розмови з дітьми на різні теми, що їх цікавлять, під час яких С. Русова радить прищеплювати норми літературної української мови; читання й оповідання творів художньої літератури, зокрема й позапрограмове; драматизація за змістом художніх творів, яку діти проводять самостійно «при найменшому втручанні педагога» ${ }^{10}$.

Т. Лубенець називав рідне слово «грунтом для науки» й наголошував: «Спостереження підтверджують, що розвиток у дітей інтересу, уваги й пам'яті - цих основних психічних функцій, без яких навчання неможливе, цілком знаходиться в повній i природній залежності від рідної мови дітей, засвоєної ними разом $з$ молоком матері» ${ }^{11}$.

Реформування освітнього процесу зумовило нове розуміння ролі та функцій учителя, що актуалізувало питання підготовки нових учительських кадрів, спрямованої на розвиток педагогіки співробітництва, набуття знань з психології, фізіології дитини, інноваційної педагогіки, відведення вчителю ролі помічника в набутті знань учнями тощо. Так, С. Русова зазначала: «Такої постаті вчителя, постаті нового Моісея, що виводить свій народ 3 тенет темряви, несвідомості, поневолення - до нового життя, вимагає сучасний стан України від учителя тої єдиної школи, де має вчитися весь український народ без жодних соціальних обмежень» ${ }^{12}$. Т. Лубенець називав дітей майбутнім, а вчителя - помічником, що відкриває двері для кожного маленького майбутнього.

Важливу роль у процесі підготовки вчителів відіграли на початку XX ст. учительські курси, організовані в Києві, Харкові, а пізніше вчительські з'їзди. На педагогічних відділах учительських курсів читалися лекції із загальної та дитячої психології, педагогіки, дидактики, анатомії, фізіології. На них курсистки отримували знання «щодо останніх досягнень світової педагогічної науки і практики, використання нестандартних методик викладання рукоділля,

10 Лінгводидактична концепція Софії Русової. URL: http://udnz15.org/ lingvodidaktichna-2 (дата звернення: 15.04.2020).

${ }^{11}$ Граматка (український буквар) 3 малюнками / склав Норець (Т. Лубенець). 4-е вид., поправл. Київ : Вид-во книгарні С. Череповського, 1917. С. 47.

${ }_{12}$ Русова С. Вибрані педагогічні твори : у 2 кн. / за ред. С.І. Коваленко ; упоряд., передм., прим. С.І. Коваленко, І.М. Пінчук. Київ : Либідь, 1997. Кн. 2. С. 240. 
малювання, ліплення, ручної праці, історії новітніх педагогічних течій, основних принципів нової педагогіки тощо» ${ }^{13}$. Вагоме значення приділялося добору високопрофесійних кадрів викладачів курсів, серед яких - О. Пономарьова, Т. Лубенець, О. Музиченко й ін.

Отже, період із 70-х років XIX ст. до 30 -х років XX ст. можна вважати періодом зростання інтересу до західних педагогічних інновацій, опанування вітчизняними педагогами провідних ідей західноєвропейської реформаторської педагогіки, зокрема англійської, а також їх активної реалізації в професійній діяльності на принципах педоцентризму, активного творчого розвитку дитини, демократизації освіти.

Однак після прийняття ЦК ВКП (б) у 1936 році постанови «Про педологічні перекручення в системі Наркомосу» припиняється будь-яке вивчення вікових та індивідуальних особливостей дітей загалом ${ }^{14}$.

Другий період - період повернення інтересу до дитини як суб'єкта навчання, що характеризується відродженням ідей реформаторської педагогіки, починається в 60-ті роки XX століття й триває до сьогодні. Його також можна поділити на два етапи: 60-ті - 80-ті роки XX століття етап відродження педології та повернення до вивчення дитячої індивідуальності, а також 90-ті роки XX століття - етап відродження національної педагогіки в період становлення незалежності держави.

Зауважимо, що перший етап (60-ті - 80-ті роки XX століття) був дуже складним для розвитку педагогічної інноваційної діяльності. Це зумовлювалося насамперед освітньою політикою, що здійснювалася в попередні роки, «коли комуністична, партійна ідеологія набула форм догматів і канонів, коли потрібно було думати й творити лише в дозволених межах» ${ }^{15}$, iï кардинальної зміни в часи «відлиги», коли зроблена спроба частково реформувати тоталітарну радянську систему, перетворити ii життєздатний суспільний організм. По-друге, 70-ті 80 -ті роки мали зовсім інший історичний зміст і характеризувалися політичною та ідеологічною реакцією та прогресуючим занепадом i розкладом тоталітарної системи ${ }^{16}$. Відповідно, зазначені політичні

${ }^{13}$ Перетятько О.В. Роль ідей реформаторської педагогіки в процесі формування інноваційного потенціалу вітчизняного вчителя (кінець XIX - початок XX століть). URL: http://studentam.net.ua/content/view/7806/85/ (дата звернення: 15.04.2020).

14 Історія педагогіки / за ред. проф. М.В. Левківського, докт. пед. наук О.А. Дубасенюк. Житомир : Житомирський державний педагогічний університет, 1999. C. 274.

15 Сухомлинська О.В. Авторські педагогічні системи як складова оновлення національної школи. Вісник Житомир. держ. ун-ту ім. І. Франка. 2007. Вип. 36. C. 25.

${ }^{6}$ Денисюк Т.Ф. Історіографічний аналіз розвитку змісту початкової освіти України у 50-90-х роках XX століття. Вісник Житомир. держ. ун-ту ім. I. Франка. 2006. Вип. 28. С. 39-42. 
умови відбилися на визначенні педагогічних пріоритетних ідей того часу, які постійно змінювалися.

Так, у 60-70-ті роки в Україні поширюється функціональний підхід до навчання й виховання, закріплений у законі «Про зміцнення зв'язку школи 3 життям та про подальший розвиток системи освіти в СРСР», відповідно до якого вводилася обов'язкова професійна підготовка в загальноосвітніх школах, подальше підвищення рівня загальної й політехнічної освіти, підготовка освічених людей, які б добре знали основи наук, виховання молоді в глибокій повазі до принципів соціалістичного суспільства, у дусі ідей комунізму ${ }^{17}$.

Отже, дослідження питання впливу ідей реформаторської педагогіки Англії на розвиток вітчизняної педагогічної науки дає змогу зробити висновок про творче використання вітчизняною наукою ідей західноєвропейської, зокрема й англійської, реформаторської педагогіки як основи для створення власних інноваційних проектів. У цьому процесі можна виділити два періоди - кінець XIX - середина 30-х років XX століття та 60-ті роки XX століття - до сьогодні, які характеризуються цікавістю науковців i педагогів-практиків до ідей реформаторської педагогіки. Перший період $є$ періодом становлення теоретичних основ реформаторського руху, вивчення основних методичних, змістових та організаційних принципів діяльності західних експериментальних навчально-виховних закладів, виникнення реформаторських течій у вітчизняній педагогіці, а також практичної реалізації їх у діяльності педагогів-новаторів, зокрема С. Русової, Т. Лубенця, А. Макаренка, Я. Чепіги. Другий період - період повернення інтересу до дитини як суб'єкта навчання, що характеризується відродженням ідей реформаторської педагогіки й формуванням національної освіти в період становлення незалежності держави.

\section{2. Вплив реформаторської педагогіки В. Сухомлинського на розвиток теорії й практики навчання та виховання в українських школах}

Саме на ці роки припадає діяльність видатного вітчизняного педагога-новатора В. Сухомлинського, якому вдалося в межах радянської парадигми виховання обгрунтувати й реалізувати на практиці гуманістичну та демократичну за своєю сутністю систему виховання ${ }^{18}$. Аналіз його діяльності свідчить про відновлення й

\footnotetext{
${ }^{17}$ Москаленко А.М. Історія вітчизняної педагогіки : навчальний посібник. Київ : Київ. нац. ун-т ім. Тараса Шевченка, 2015.

18 Адаменко О.В. Розвиток педагогічної науки в Україні в другій половині ХХ ст. (1950-2000 рр.) : автореф. дис. ... докт. пед. наук : 13.00.01. Луганськ, 2006. C. 25 .
} 
розвиток головних ідей західноєвропейської реформаторської педагогіки: повага та любов до дитини; розвиток творчих здібностей кожної дитини, починаючи 3 дошкільного віку, метою якого $\epsilon$ підготовка до творчої праці; формування екологічних цінностей, почуття прекрасного; упровадження методів і засобів навчання та виховання, притаманних педагогіці гуманізму, - акцент на позитивному, відсутність покарання, повага до особи учня тощо.

Основною метою педагогічної діяльності В. Сухомлинського залишалося формування всебічно розвинутої особистості. Як зауважує О. Сухомлинська, принципами досягнення цієї мети $є$ любов, довіра й повага до дитячої особистості, розгляд навчальної діяльності школярів як насиченого творчими відкриттями процесу пізнання та самопізнання через слово, особистість учителя, працю, розвиток творчих сил кожної окремої особистості в умовах колективної співдружності на основі етико-естетичних цінностей, інтересів, потреб, спрямований у кінцевому підсумку на творчу працю, культури почуттів, естетизацію навколишнього середовища ${ }^{19}$.

В умовах гуманізації виховання В. Сухомлинський по-новому осмислював сутність взаємин колективу й кожного вихованця, розвивав ідеї А. Макаренка щодо виховного впливу колективу на дитячу особистість. У роботах «Виховання колективізму у школярів», «Духовний світ школяра», «Розмова з молодим директором школи» він установлює принципи взаємозалежностей особистості й колективу. На його думку, колектив лише тоді позитивно впливає на становлення кожного вихованця, коли сам має насичене духовне життя та складається з яскравих особистостей. За цих умов кожен вихованець здатен впливати на загальний стиль взаємин у колективі, збагачуючи при цьому один одного, що дасть змогу гармонізувати взаємини в дитячому співтоваристві.

Як i засновники «нових шкіл» С. Редді, Дж.Г. Бедлі, новими школами в Англії в середині XIX століття почали називати щойно відкриті приватні школи, які дещо змістили акцент у роботі 3 виховання на навчання, які прагнули підготувати своїх учнів до вступу до університетів, озброїти їх утилітарними, корисними знаннями, дати їм не стільки класичну, скільки реальну освіту, яка допомогла б їм у дорослому житті. О. Сухомлинський уважав за необхідне поєднання інтелектуального розвитку учнів з творчою працею. Особливу увагу при цьому він приділяв малюванню, наголошуючи, що саме воно

${ }^{19}$ Сухомлинська О.В. Авторські педагогічні системи як складова оновлення національної школи. Вісник Житомир. держ. ун-ту ім. І. Франка. 2007. Вип. 36. C. 25 . 
сприяє розвитку мови, логічного мислення, опануванню точних наук, зокрема математики: «Якщо дитина навчилась малювати задачі, я 3 певністю міг сказати, що розв'язувати їх вона буде» ${ }^{20}$. Зв' язок навчання 3 творчістю дав змогу впровадити нові форми й методи навчання: «уроки мислення на природі», «школа під голубим небом», «школа радості», комплексну програму «виховання красою», «друга програма навчання», «інтелектуальний фон школи», методику формування «культури почуттів», «радості пізнання», «радості праці» тощо.

Велику увагу педагог приділяв питанню підготовки вчителів, при цьому розуміючи, що далеко не кожен може й повинен бути учителем. У праці «Сто порад учителю» він радив починати пробувати себе в цій професії ще навчаючись у старших класах: «У вас зародилася мрія стати вчителем. Перевірте, випробуйте себе. Ви навчаєтеся в дев'ятому чи в десятому класі, попросіться побути вихователем групи діточок у молодшому класі. ... Якщо цей світ відкриється перед вами, якщо в кожній дитині ви відчуєте іiі індивідуальність, якщо у ваше серце постукають радощі й прикрощі кожної дитини й відізвуться вашими думками, турботами, тривогами, - сміливо вибирайте своєю професією благородну вчительську працю, ви знайдете в ній радість творчості». І далі продовжує: «Учительська професія - це людинознавство, постійне проникнення в складний духовний світ людини, яке ніколи не припиняється» ${ }^{21}$. У цій же праці В. Сухомлинський виокремлює ознаки, що характеризують специфіку праці педагога: «а) ми маємо справу 3 найскладнішим, неоціненним, найдорожчим, що $\epsilon$ в житті, - 3 людиною. Від нас, від нашого вміння, майстерності, мистецтва, мудрості залежить іiі життя, здоров'я, розум, характер, воля, громадянське й інтелектуальне обличчя, піï місце і роль у житті, іiі щастя; б) кінцевий результат педагогічної праці можна побачити не сьогодні, не завтра, а через дуже тривалий час; в) на дитину впливає багато людей і явищ життя, на неї впливають мати, батько, шкільні товариші, так зване «вуличне середовище», прочитані книжки й переглянуті кінофільми, про які ви й не знаєте, зовсім непередбачена зустріч 3 людиною і т. ін. Місія школи, наше 3 вами найважливіше завдання - боротися за людину, переборювати негативні впливи i давати простір позитивним; г) об'єкт нашої праці - найтонші сфери духовного життя особистості, яка формується, - розум, почуття, воля, переконаність, самосвідомість; д) однією 3 найважливіших

${ }^{20}$ Сухомлинський В.О. Вибрані твори : у 5 т. Київ : Радянська школа, 1976. Т. 2. C. 507.

${ }^{21}$ Сухомлинський В.О. Сто порад учителеві. Вибрані твори : у 5 т. Київ : Радянська школа, 1976. Т. 2. 
особливостей творчості педагога $є$ те, що об'єкт його праці - дитина повсякчас змінюється, завжди новий, сьогодні не той, що вчора».

Отже, школу В. Сухомлинського можна визначити як школу гуманізму, школу духовності, моральності й культури, школу особистостей та індивідуальностей, школу, яка вдивлялася й занурювалася у світ дитинства 22 .

Невипадково як протест проти традиційної системи навчання й виховання в авторитарній державі зароджується новий напрям у педагогіці - педагогіка співробітництва, яка стала основною засадою навчально-виховного процесу в «інноваційних» та «авторських» школах того часу.

Педагогіку співробітництва Ш. Амонашвілі визначав як «могутній струмінь гуманної педагогіки. Гуманна педагогіка вбирає в себе педагогіку співробітництва, дає іiі філософське обгрунтування», а іiі мету вбачав у необхідності «зробити дитину нашим (дорослих учителів, вихователів, батьків) добровільним соратником, співробітником, однодумцем у своєму ж вихованні, освіті, навчанні, становленні, зробити ii рівноправним учасником педагогічного процесу, дбайливим i відповідальним за цей процес, за його результати» ${ }^{23}$. Термін «педагогіка співробітництва» вперше з'явився в Маніфесті «Педагогіка співробітництва» (1986 рік), підписаному сімома педагогами-новаторами (С. Лисенкова, В. Шаталов, І. Волков, В. Караковський, М. Щетинін, С. Ільїн, Ш. Амонашвілі), які виклали в ньому власний досвід роботи, узагальнивши його в таких основних засадах педагогіки співробітництва: увага вчителя до учнів, залучення їх до навчання, пробуджуючи в них почуття успіху, руху вперед, розвитку; віра в можливості дитини подолати будь-які труднощі шляхом постановки найважчої мети; навчання без примусу; особистісний підхід до дитини; ідея вільного вибору, що полягає у вільному виборі учнями завдань, складанні їх для своїх однокласників тощо; ідея випередження та складних блоків, що дає змогу включати до програми більш складний матеріал, об'єднувати його в блоки тощо; самоаналіз і колективний аналіз діяльності кожного учня; засада колективної суспільної творчості; співпраця з батьками; співробітництво вчителів у процесі навчання та виховання учнів.

Видатний вітчизняний педагог-новатор В. Шаталов зауважував: «Найголовніше - учитель повинен допомогти учневі усвідомити себе

22 Сухомлинська О.В. Авторські педагогічні системи як складова оновлення національної школи. Вісник Житомир. держ. ун-ту ім. І. Франка. 2007. Вип. 36. C. 26 .

Амонашвили Ш.А. Размышления о гуманной педагогике. Москва : Издательский дом Шалвы Амонашвили, 1996. С. 47. 
особистістю, пробудити потребу в пізнанні себе, життя, світу, виховати в ньому почуття людської гідності... Від віри вчителя в можливості кожного свого учня, від його наполегливості й терпіння, уміння вчасно прийти на допомогу залежать успіхи його учнів на важкому шляху пізнання» ${ }^{24}$. О. Захаренко наголошував: «У школі учню має бути, як в батьківській хаті. До школи він має бігти, а не йти, знаючи, що в школі він пізнає радість відкриття своєї сутності в цьому мінливому світі. В школі його не образять, на нього не гримнуть, а порадять, підтримають, дадуть можливість розкрити себе, свою творчу обдарованість» ${ }^{25}$.

Як бачимо, наведені засади об'єднані спільною основною ідеєю педагогіки співробітництва, яка перегукується з ідеями, визначеними реформаторською педагогікою: дитина стає центром педагогічного процесу, учитель перетворюється 3 наставника на порадника, який допомагає учневі розкрити свій потенціал, досягти будь-якої мети, виховує самостійне мотивоване ставлення до навчання.

Новим сплеском відродження, переосмислення та наслідування ідей західноєвропейської реформаторської педагогіки характеризуються 90ті роки XX століття до сьогодення - етапу становлення незалежної України.

3 розпадом СРСР, проголошенням суверенної української держави стали можливими демократичні зміни в системі освіти, які передбачали розроблення власної національної системи освіти, відмову від ідеологізації та русифікації освіти, виведення вітчизняної освіти на рівень розвинутих країн світу.

В ухваленому в 1991 році Законі України «Про освіту» регламентовано: «Метою освіти $\epsilon$ всебічний розвиток людини як особистості та найвищої цінності суспільства, розвиток іiі талантів, розумових i фізичних здібностей, виховання високих моральних якостей, формування громадян, здатних до свідомого суспільного вибору, збагачення на цій основі інтелектуального, творчого, культурного потенціалу народу, підвищення освітнього рівня народу, забезпечення народного господарства кваліфікованими фахівцями» ${ }^{26}$.

Національна доктрина розвитку освіти (2002 рік) визначає особистісну орієнтацію освіти пріоритетним напрямом державної політики, а мета державної політики щодо розвитку освіти полягає у

${ }^{24}$ Шаталов В.Ф. Точка опоры: организационные основы экспериментальных исследований. Минск : Университетское, 1990. С. 92.

${ }_{25}$ Захаренко О.А. Поспішаймо робити добро. Черкаси, 1997. С. 17.

26 Про освіту : Закон Верховної Ради УРСР від 23.05.1991 № 1060-XII. URL: http://zakon2.rada.gov.ua/laws/show/1060-12 (дата звернення: 18.04.2020). 
створенні умов для розвитку особистості й творчої самореалізації кожного громадянина України ${ }^{27}$.

Отже, як бачимо, людина, розвиток іiі здібностей проголошуються найвищою цінність держави, що $є$ провідною ідеєю реформаторської педагогіки.

Окрім того, інтеграція України в європейський освітній простір актуалізує й інші провідні ідеї реформаторської педагогіки - ідеї свободи, рівності, особистої гідності. Усі вони відображені в запропонованих МОН України Концептуальних засадах реформування середньої освіти «Нова українська школа» ${ }^{28}$. У цьому документі зазначається необхідність працювати на засадах педагогіки партнерства, основними принципами якої є спілкування, повага до особистості; взаємодія та співпраця між учителем, учнем і батьками; довіра у взаєминах. Діалог і багатостороння комунікація між учнями, учителями та батьками змінить односторонню авторитарну комунікацію вчитель - учень.

По-друге, Концептуальні засади реформування середньої освіти «Нова українська школа» закріплюють ідею дитиноцентризму: нова українська школа буде працювати на засадах особистісно орієнтованої моделі освіти. У рамках цієї моделі школа максимально враховує здібності, потреби й інтереси кожної дитини, на практиці реалізуючи принцип дитиноцентризму.

По-третє, актуальною залишається ідея формування нового вчителя. У Концептуальних засадах зазначено, що нова школа потребує нового вчителя, не як єдиного наставника та джерело знань, а як коуча, фасилітатора, тьютора, модератора в індивідуальній освітній траєкторії дитини. При цьому держава гарантує академічну свободу, яка полягає в можливості готувати власні авторські навчальні програми, власноруч обирати підручники, методи, стратегії, способи й засоби навчання; активно виражати власну фахову думку, а також гідне матеріальне забезпечення.

По-четверте, нагальною залишається ідея формування активного громадянина, відповідно до якої нова українська школа створюватиме ціннісні ставлення й судження, які слугуватимуть базою для щасливого особистого життя та успішної взаємодії із суспільством, плекатимуть українську ідентичність, а також виховуватимуть відповідальність не лише за себе, а й за розвиток і добробут країни та всього людства за моделлю поваги до прав людини, демократії, підтримки добрих ідей.

${ }^{27}$ Про Національну доктрину розвитку освіти : Указ Президента від 17.04.2002 № 347/2002. URL: http://zakon2.rada.gov.ua/laws/show/347/2002 (дата звернення: 16.04.2020).

${ }^{28}$ Нова українська школа: концептуальні засади реформування середньої школи. URL: http://mon.gov.ua/\%D0\%9D\%D0\%BE\%D0\%B2\%D0\%B8\%D0\%BD\%D0\%B8\% 202016/08/21/2016-08-17-3-.pdf (дата звернення: 18.04.2020). 
По-п’яте, у Концептуальних засадах відображена ідея автономії школи: адміністративні й навчально-методичні повноваження будуть делегуватися на рівень закладу освіти. Автономія передбачає, що школи зможуть самостійно формувати освітні програми, складати навчальні плани і програми 3 навчальних предметів відповідно до стандартів середньої освіти, обирати підручники, методики навчання й виховання, розвивати навчально-матеріальну базу.

Теоретичне осмислення вітчизняними науковцями ідей дитиноцентризму, педагогіки партнерства, автономії школи, формування особистості нового вчителя, формування активного громадянина тощо сприяє їх реалізації в сучасній вітчизняній педагогічній науці шляхом децентралізації освіти, створення авторських шкіл, індивідуалізації навчання.

\section{ВИСНОВКИ}

Навчальні програми в нових українських школах сприяють вивченню великої кількості фактичного матеріалу, що, у свою чергу, розширює кругозір учнів. Велика увага в навчальному процесі приділялася фізичному розвитку та практичній діяльності, удосконаленню трудових умінь і навичок, що сприяє прагненню педагогів цих шкіл поєднати життя 3 навчальною діяльністю. Формуючи дидактичні принципи, засновники цих навчально-виховних закладів виходять від дитини, іiі інтересів i вподобань, особливостей розвитку іiі психіки. Такими принципами $\epsilon$ принцип педоцентризму, свободи, поваги й довіри до дитячої особистості, а головна ідея педагогічної діяльності полягала в утіленні їх у практику виховання. Своє покликання педагоги цих шкіл убачають у вихованні громадських лідерів, здатних відновити престиж у нових соціальних та економічних умовах, що втілено в організації дитячого самоврядування. Проект «Нова українська школа» був досить вдалим відгуком на суспільні очікування оновлення змісту й форм освіти, знайшов багато прихильників і послідовників.

У ході дослідження встановлено вплив ідей реформаторської педагогіки на розвиток вітчизняної педагогічної науки. Аналіз наукових джерел свідчить про різні періоди активізації інтересу до ідей зарубіжної реформаторської педагогіки кінця XIX - початку XX століття у вітчизняній педагогіці. Перший період визначається науковцями 3 кінця XIX століття до 1919 року та другий період 20-ті - 30-ті роки XX століття. Перший період характеризується становленням теоретичних основ реформаторського руху, вивченням основних методичних, змістовних та організаційних принципів діяльності західних експериментальних навчально-виховних закладів, виникненням реформаторських течій у вітчизняній педагогіці. 
Основним підходом до організації навчально-виховної діяльності у вітчизняній педагогіці, що сформувався під впливом західноєвропейського реформаторського руху, став педоцентричний, за якого дитина $\epsilon$ центром навчального та виховного процесу, спрямованого на забезпечення ії інтересів і прагнень, розвиток трудових і пізнавальних здібностей, формування умов для саморозвитку й самовиховання.

Другий період - 20-ті - 30-ті роки XX століття, характеризується реформуванням освітнього процесу, що зумовило нове розуміння ролі та функцій учителя, актуалізувало питання підготовки нових учительських кадрів, спрямованої на розвиток педагогіки співробітництва, набуття знань 3 психології, фізіології дитини, інноваційної педагогіки, відведення вчителю ролі помічника в набутті знань учнями.

Установлено, що період із 20-х по 30-ті роки XX століття можна вважати періодом зростання інтересу до західних педагогічних інновацій, опанування вітчизняними педагогами провідних ідей західноєвропейської реформаторської педагогіки, зокрема англійської, а також їх активної реалізації в професійній діяльності на принципах педоцентризму, активного творчого розвитку дитини, демократизації освіти.

Саме на ці роки припадає діяльність видатного вітчизняного педагога-новатора В. Сухомлинського, якому вдалося в межах радянської парадигми виховання обгрунтувати та реалізувати на практиці гуманістичну й демократичну за своєю сутністю систему виховання. Аналіз його діяльності свідчить про відновлення та розвиток головних ідей західноєвропейської реформаторської педагогіки: повага і любов до дитини; розвиток творчих здібностей кожної дитини, починаючи 3 дошкільного віку, метою якого $\epsilon$ підготовка до творчої праці; формування екологічних цінностей, почуття прекрасного; упровадження методів і засобів навчання та виховання, притаманних педагогіці гуманізму, - акцент на позитивному, відсутність покарання, повага до особи учня.

У процесі дослідження визначено, що інтеграція України в європейський освітній простір актуалізує й інші провідні ідеї реформаторської педагогіки - ідеї свободи, рівності, особистої гідності. Усі вони відображені в запропонованих МОН України Концептуальних засадах реформування середньої освіти «Нова українська школа». У цьому документі зазначається необхідність працювати на засадах педагогіки партнерства, основними принципами якої є спілкування, повага до особистості; взаємодія та співпраця між учителем, учнем і батьками; довіра у взаєминах. Діалог і багатостороння комунікація між учнями, учителями та батьками змінить односторонню авторитарну комунікацію вчитель - учень. 
Актуальною залишається ідея формування нового вчителя. Нова школа потребує нового вчителя, не як єдиного наставника та джерело знань, а як коуча, фасилітатора, тьютора, модератора в індивідуальній освітній траєкторії дитини. При цьому держава гарантує академічну свободу, яка полягає в можливості готувати власні авторські навчальні програми, власноруч обирати підручники, методи, стратегії, способи й засоби навчання; активно виражати власну фахову думку, а також гідне матеріальне забезпечення.

Важливою залишається ідея формування активного громадянина, відповідно до якої нова українська школа створюватиме ціннісні ставлення й судження, які слугуватимуть базою для щасливого особистого життя та успішної взаємодії із суспільством, плекатимуть українську ідентичність, а також виховуватимуть не лише відповідальність за себе, а й за розвиток і добробут країни та всього людства за моделлю поваги до прав людини, демократії, підтримки добрих ідей.

\section{АНОТАЦІЯ}

У науковій роботі розглядаються ідеї реформаторської педагогіки, що вплинули на становленню нової української школи й дали розвиток становленню нової української школи. Реформи у сфері освіти ставлять завдання більш якісної освіти порівняно 3 попередньою. Продуктивність застосування ідей реформаторської педагогіки простежується в аналізі якості освіти, мотивації та інтересу до педагогічного процесу як з боку вчителя, так і з боку учнів. В основних своїх положеннях, принципах і методиках реформаторська педагогіка довела свою ефективність. Водночас вона може вдосконалюватися й видозмінюватися в будь-яких напрямах, залежно від тих потреб і цілей, які переслідує сам педагог, сучасна педагогічна наука чи суспільство загалом. Розвиток світових суспільних відносин і наук знову потребує виховання нової самостійної особистості; особистості, яка швидко орієнтується в умовах стрімкого розвитку; здатної вирішувати поставлені перед нею цілі й приймати виважені та грамотні рішення. Ретельний аналіз, критичне осмислення педагогічної спадщини реформаторської педагогіки й застосування ऑï ідей у сучасному освітньому процесі допоможуть i надалі укріплювати принципи побудови «нової української школи».

\section{ЛITЕРАТУРА}

1. Адаменко О.В. Розвиток педагогічної науки в Україні в другій половині XX ст. (1950-2000 рр.) : автореф. дис. ... докт. пед. наук : 13.00.01. Луганськ, 2006. 44 с.

2. Амонашвили Ш.А. Размышления о гуманной педагогике. Москва : Издательский дом Шалвы Амонашвили, 1996. 496 с. 
3. Бауманн Ю. Введение в педагогику. История педагогических теорий: Общая педагогика. Санкт-Петербург : Тип. М.О. Вольфа, 1905. $150 \mathrm{c}$.

4. Граматка (український буквар) 3 малюнками / склав Норець (Т. Лубенець). 4-е вид., поправл. Київ : Вид-во книгарні Є. Череповського, 1917. 48 с.

5. Денисюк Т.Ф. Історіографічний аналіз розвитку змісту початкової освіти України у 50-90-х роках XX століття. Вісник Житомир. держ. ун-ту ім. I. Франка. 2006. Вип. 28. С. 39-42.

6. Захаренко О.А. Поспішаймо робити добро. Черкаси, 1997. 28 с.

7. Історія педагогіки / за ред. проф. М.В. Левківського, докт. пед. наук О.А. Дубасенюк. Житомир : Житомирський державний педагогічний університет, 1999. 336 с.

8. Карпенчук С. Педагогічні ідеї А.С. Макаренка: гуманістичні контексти. Нова педагогічна думка. Київ, 2014. № 4. С. 118-124.

9. Левківський М.В. Історія педагогіки : навчально-методичний посібник. 4-те вид. Київ : Центр учбової літератури, 2011. 190 с.

10. Лінгводидактична концепція Софії Русової. URL: http://udnz15.org/lingvodidaktichna-2 (дата звернення: 15.04.2020).

11. Макаренко А.С. Методика виховної роботи. Київ : Радянська школа, 1990. 366 с.

12. Макаренко А.С. Педагогические сочинения : в 8 т. / сост. : А.А. Фролов, Л.Ю. Гордин, М.Д. Виноградова. Москва, 1983-1986.

13. Москаленко А.М. Історія вітчизняної педагогіки : навчальний посібник. Київ : Київ. нац. ун-т ім. Тараса Шевченка, 2015. 303 с.

14. Нова українська школа: концептуальні засади реформування середньої школи. URL:http://mon.gov.ua/\%D0\%9D\%D0\%BE\%D0\%B2\% D0\%B8\%D0\%BD\%D0\%B8\%202016/08/21/2016-08-17-3-.pdf (дата звернення: 18.04.2020).

15. Осьмук Н.Г. Ідеї реформаторської педагогіки в дослідженнях українських освітніх діячів $20-\mathrm{x}$ - початку $30-\mathrm{x}$ років XX століття : автореф. дис. ... канд. пед. наук : 13.00.01. Суми : Сум. держ. пед. ун-т ім. А.С. Макаренка, 2011. 20 с.

16. Перетятько О.В. Роль ідей реформаторської педагогіки в процесі формування інноваційного потенціалу вітчизняного вчителя (кінець XIX - початок XX століть). URL: http://studentam.net.ua/ content/view/7806/85/ (дата звернення: 15.04.2020).

17. Про Національну доктрину розвитку освіти : Указ Президента від 17.04.2002 № 347/2002. URL: http://zakon2.rada.gov.ua/laws/ show/347/2002 (дата звернення: 16.04.2020).

18. Про освіту : Закон Верховної Ради УРСР від 23.05.1991 № 1060-XII. URL: http://zakon2.rada.gov.ua/laws/show/1060-12 (дата звернення: 18.04.2020). 
19. Грушевський М. Про українську мову і українську школу / передм. Я. Гояна. 2-е вид. Київ : Веселка, 1991. 45 с.

20. Русова С. Вибрані педагогічні твори : у 2 кн. / за ред. Є.І. Коваленко ; упоряд., передм., прим. Є.І. Коваленко, І.М. Пінчук. Київ : Либідь, 1997. Кн. 2. 320 с.

21. Русова С. Дошкільне виховання. Катеринослав, 1918. 163 с.

22. Русова С.Ф. Дидактика. Вибрані пед. твори : у 2 кн. Київ : Либідь, 1997. Кн. 2. С. 134-300.

23. Сухомлинська О.В. Авторські педагогічні системи як складова оновлення національної школи. Вісник Житомир. держ. ун-ту ім. І. Франка. 2007. Вип. 36. С. 24-27.

24. Сухомлинський В.О. Вибрані твори : у 5 т. Київ : Радянська школа, 1976. Т. 2. 1976.

25. Сухомлинський В.О. Сто порад учителеві. Вибрані твори : у 5 т. Київ : Радянська школа, 1976. Т. 2.

26. Харук Т.Я. Становлення закладів для дітей-сиріт та дітей, позбавлених батьківського піклування, на різних етапах розвитку суспільства в Україні. Збірник наукових працьь Хмельницького інституту соиіальних технологій Університету «Украӥна». 2011. № 3. C. 189-192. URL: http://nbuv.gov.ua/UJRN/Znpkhist_2011_3_41 (дата звернення: 18.04.2020).

27. Чепіга Я. Національність і національна школа. Світло. 1910. № 1. C. 16-29.

28. Чепіга Я.Ф. Самовиховання вчителя. Київ : Українська педагогічна бібліотека, 1914. $36 \mathrm{c.}$

29. Шаталов В.Ф. Точка опоры: организационные основы экспериментальных исследований. Минск : Университетское, 1990. 224 с.

\section{Information about the authors:} Testsova O. O., Ph.D. in Pedagogic Sciences, Associated Professor at the Department of Languages and Humanities № 2 Donetsk National Medical University 1, Velyka Perspektyvna str., Kropyvnytskyi, Ukraine

Pyshnohub M. V., Lecturer at the Department of Languages and Humanities № 2 Donetsk National Medical University 1, Velyka Perspektyvna str., Kropyvnytskyi, Ukraine 